\title{
Reaction of wheat plants and alternative hosts to Magnaporthe oryzae
}

\section{Reação de plantas de trigo e hospedeiros alternativos a Magnaporthe oryzae}

\author{
Lucas Gustavo Yock Durante ${ }^{1 *}$, Lilian Maria Arruda Bacchi ${ }^{1}$, Jessica Evangelista de Souza ${ }^{2}$, \\ Felipe André Sganseria Graichen ${ }^{3}$
}

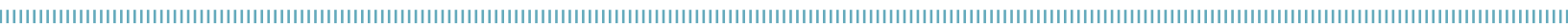

\begin{abstract}
Blast disease, caused by the fungus Magnaporthe oryzae, has a major impact on wheat farming. The study of plant responses to pathogens has improved the management of this disease. Moreover, it is important to identify potential host plants in the crops' vicinity and to understand reactions caused by plantpathogen interactions. The objective of this study was to assess the histopathology of wheat plants, Digitaria insularis and Digitaria sanguinalis inoculated with $M$. oryzae isolates obtained either rice or wheat plants. Thirty-three days after sowing, greenhouse-grown plants of all three species were inoculated with each $M$. oryzae isolate. The observed effects ( 48 hours after inoculation) differed depending on the particular interaction between each pathogen isolate-plant species pair. For instance, wheat and $D$. sanguinalis had the weakest defensive response against spore germination, production of melanized appressoria, and appressorial penetration, with average values above 87,90 , and $43 \%$, respectively, for these events in these plants. Furthermore, germination and appressoria melanization were more aggressive in the rice isolate than in the wheat isolate. Additionally, evidence for a defensive response (such as cell death) was observed in wheat plants inoculated with rice isolates. However, such a response was absent in plants inoculated using wheat isolates, presumably because pathogen recognition failed.
\end{abstract}

KEYWORDS: blast disease; Digitaria insularis; Digitaria sanguinalis; wheat; histopathology.
RESUMO: A brusone é uma doença causada pelo fungo Magnaporthe oryzae e de grande impacto para a triticultura. $\mathrm{O}$ estudo das respostas da planta aos patógenos tem auxiliado no manejo das doenças, e a identificação das plantas hospedeiras nas proximidades da lavoura é importante, assim como conhecer as reaçóes de interação com o patógeno. O objetivo deste estudo foi determinar os eventos histológicos de plantas de trigo Digitaria insularis e Digitaria sanguinalis inoculadas com isolados de $M$. oryzae de plantas de arroz e trigo. Aos 33 dias da semeadura, as plantas cultivadas em estufa foram inoculadas com dois isolados de $M$. oryzae. O efeito observado nas plantas, 48 horas após a inoculação, mostrou interações diferentes para cada isolado do patógeno e entre as espécies de plantas. As plantas de trigo e $D$. sanguinalis foram os materiais com menores respostas de defesa à germinaçáo, de produção de apressórios melanizados e penetração do apressório, com valores acima de 87, 90 e 43\%, respectivamente. Entre os isolados do patógeno, o mais agressivo para germinação e produção de apressório melanizado foi o proveniente de plantas de arroz. A resposta de defesa da planta, como a morte celular, foi observada nas plantas de trigo inoculadas com isolado proveniente de plantas de arroz, enquanto náo houve resposta de defesa da planta quando inoculada com isolado obtido de plantas de trigo, provavelmente por não ocorrer o reconhecimento do patógeno.

PALAVRAS-CHAVE: brusone; Digitaria insularis; Digitaria sanguinalis; trigo; histopatologia. 


\section{INTRODUCTION}

Common wheat Triticum aestivum $\mathrm{L}$. is the most widespread crop in the world. In Brazil, it was initially established in the coldest regions of the country, in the states of Rio Grande do Sul, Santa Catarina, and southern Paraná. Over the past nearly 20 years, various states have demonstrated their propensity for wheat production, i.e., Minas Gerais, Goiás, Federal District, Mato Grosso do Sul, Mato Grosso, and Bahia (GOULART et al., 1995). In 2016, Brazil produced 6.7 million tons of wheat in 2.1 million hectares (CONAB, 2017). The southern areas of the country are the region accounting for the largest production, having the harvest concentrated in a single period from mid-October to December (BRAGAGNOLO et al., 2007).

Blast disease is of significant importance in wheat farming, and it is caused by the fungus Magnaporthe oryzae B. C. Couch (anamorphic Pyricularia oryzae Cavara). In 1637, this disease was initially reported in rice farms in China and Japan (BEDENDO; PRABHU, 2005). However, in 1985, the first wheat infection was reported in Brazil, in the north of Paraná (IGARASHI et al., 1986), and since then it has been found in other producing regions of the country, as well as other LatinAmerican countries. Various aspects related to this disease have been the object of study, including optimal infection temperature, dissemination of the pathogen, application of fungicides, and even sources of resistance in wheat cultivars and host-pathogen interactions (URASHIMA et al., 2007; CRUZ et al., 2010).

The symptoms of the disease in wheat leaves are the presence of elliptic lesions, gray in the center and brown on the margins. On the ears, a premature discoloration (bleaching) occurs on the ear portion above the pathogen's infection point, whereas on the rachis dark-bright lesions are restricted to the area around the point of infection. Importantly, crop productivity is reduced due to a decrease in grain size; this difference becomes visible in the affected ear even before harvest (LIMA, 2004). The damages caused by blast disease were up to $32.3 \%$ in the region of Dourados (in the state of Mato Grosso do Sul), where it was observed yield reductions reached 1,660 kg.ha-1 (GOULART et al., 2007).

Disease management is a critical aspect of wheat farming. However, chemical control is inefficient, owing to the difficulty of ensuring that the fungicide penetrates to the ears, making application economically unfeasible. Consequently, the use of resistant varieties has become an increasingly important control measure because of its relatively low cost. Nevertheless, achieving resilient resistance in plants governed by a single gene is unlikely owing to the high mutation rates of the fungus, resulting in infection owing to the breakdown of genotypic resistance (ROCHA et al., 2014; ARAÚJO et al., 2000).

Plant resistance responses to pathogens depend on gene expression resulting in observable histological effects, such as cell death, in response to the product of the pathogen's avirulence genes, pathogen toxins, or other factors (YAO et al., 2002). Cell death may be an indicator of resistance response to pathogens if accompanied by a reduction in infection rate. However, the effect of cell death is variable and differs ultrastructurally in each pathogen-host interaction (GRAICHEN et al., 2011).

Rotation management is particularly important to decrease the initial inoculum of the pathogen, as other plant species may be hosts of the genus Magnaporthe and allow sexual reproduction of Pyricularia oryzae, which would result in increased damage to crops of interest such as wheat or rice. The control of weeds and alternative hosts around these crops should be carried out, as pathogens can infect several grass species (MOREIRA et al., 2015), as was observed by GALBIERI; URASHIMA (2008) in Digitaria insularis and Digitaria sanguinalis, among other species.

The objective of this study was to assess the histopathology of wheat $D$. insularis and $D$. sanguinalis inoculated with $M$. oryzae isolates obtained from either rice or wheat plants.

\section{MATERIALS AND METHODS}

The experiment was conducted from June 26 to August 28, 2015, at the demonstration unit of the University of Aquidauana, State University of Mato Grosso do Sul, Mato Grosso do Sul, Brazil. Pots with 7-liter capacity were filled using Carolina substrate to sow host plant seeds (1-2 cm deep): wheat (cultivar Coodetec 150), D. insularis, and D. sanguinalis (both Digitaria species were collected in Dourados, Mato Grosso do Sul). The plants were inoculated with $M$. oryzae 33 days after sowing.

\section{Inoculation and fungal isolates used}

The two M. oryzae isolates were obtained from rice and wheat plants collected in the region of Pelotas, Rio Grande do Sul, and Dourados, Mato Grosso do Sul; they were recovered using $\mathrm{V} 8$ medium $\left(200 \mathrm{~mL}\right.$ of $\mathrm{V} 8^{\circ}$ vegetable juice, $3 \mathrm{~g}$ of $\mathrm{CaCO}_{3}$, $12 \mathrm{~g}$ of agar supplemented with distilled water to a volume of $1 \mathrm{~L}$ ). Colonies were transferred to petri dishes containing oat agar medium ( $60 \mathrm{~g}$ of oat flakes, $12 \mathrm{~g}$ of agar, and $5 \mathrm{~g}$ of dextrose supplemented with enough distilled water to reach $1 \mathrm{~L}$ ) and maintained for $12-16$ days at a temperature of $27^{\circ} \mathrm{C}$ with constant light from fluorescent lamps. On the $12^{\text {th }}$ day, the fungal colonies were subjected to stress by lightly passing a Drigalski Strap over them. Then, the plates were kept in a moist chamber for spore production, after which an inoculum suspension was produced by washing plates containing isolates with an inoculation solution (3\% gelatin, $0.01 \%$ Tween 20 in distilled water) and adjusted to a density of $2 \times 10^{4}$ spores $\mathrm{mL}^{-1}$.

Inoculation was performed by spraying the spore suspension on the leaf adaxial lamina, and the inoculated plants were maintained for 24 hours in a darkroom with relative humidity near the saturation point and the temperature of $25^{\circ} \mathrm{C}$. Subsequently, plants were transferred to a growth chamber, where they remained until evaluation or sample collection. 


\section{Histopathological analysis of the plant-pathogen interaction}

Samples from inoculated leaves of wheat and Digitaria plants were collected 48 hours after inoculation (hai). For each plant, fragments approximately $1 \mathrm{~cm}$ long were collected from the middle region of the leaves. The replicates were composed of one fragment, for a total of four replicates for each plant-pathogen combination. Three replicates were used to evaluate cell death, according to the following methods.

\section{Cell death evaluation}

The leaf segments were bleached and fixed for a period of 24 hours in an ethanol:chloroform (3:1, v:v) solution with $0.15 \%$ trichloroacetic acid. After this, they were either stained or stored in a $50 \%$ glycerol solution. The segments were stained using a $0.03 \%$ trypan blue solution in lactophenol:ethanol (1:2, v:v), heated between 90 and $100^{\circ} \mathrm{C}$ for $5 \mathrm{~min}$. Afterwards, the samples were immersed in a saturated chloral hydrate solution $(5: 2, w: v)$, for bleaching and storage. Stained leaf segments were mounted with the adaxial surface facing upwards in $50 \%$ glycerol, covered by a cover slip and sealed with enamel (GRAICHEN et al., 2011). The presence of host cell death is indicated by intense staining with trypan blue, which has an affinity for dead plant tissues and for cell wall constituents of fungi and stramenopiles (WEES, 2008).

In each lamina, the following features were quantified throughout the fragment: germinated spores with appressorium differentiation, melanization of appressoria, fungal penetration of plant tissue, and cell death associated with fungal penetration. Moreover, the proportions of these events were calculated (in percentages) using the following formulas:

- for germinated spores $($ Equation 1$)=$

$(\mathrm{N} 1 /(\mathrm{N} 0+\mathrm{N} 1)) \times 100$

- for melanized appressoria (Equation 2) = $(\mathrm{N} 2 / \mathrm{N} 1) \times 100$

- for appressoria with penetration (Equation 3$)=$ $(\mathrm{N} 3 / \mathrm{N} 2) \times 100$

- $\quad$ for cell death $($ Equation 4$)=$ $(\mathrm{N} 4 / \mathrm{N} 3) \times 100$

In which:

N0 = number of non-germinated spores;

$\mathrm{N} 1=$ number of germinated spores;

$\mathrm{N} 2$ = number of melanized appressoria;

N3 = number of melanized appressoria with intracellular hyphae development (adapted from WYSS; MÜLLERSCHÄRER, 1999);
$\mathrm{N} 4$ = number of appressoria, in which plant tissue reacted positively to trypan blue staining.

\section{Data analysis}

The data were arcsine-transformed from the root of $x / 100$ and subjected to analysis of variance. Averages were compared using the Tukey test 5\%, employing the software SANEST.

\section{RESULTS AND DISCUSSION}

The percentage of germinated spores differed significantly among evaluated species, with results of 95,87 , and $19 \%$ for wheat, $D$. sanguinalis, and D. insularis, respectively. It suggests that different species present distinct germination conditions for M. oryzae spores (Table 1). The presence of intensely stained appressoria in germinated spores was used to characterize them as melanized, which would indicate the possibility of successful fungal penetration through opening a hole in the leaf epidermis. The percentage of germinated spores that formed appressoria was similar among the different combinations of isolated pathogens and host plants (Tables 1 and 2). Approximately $71-97 \%$ of the germinated spores progressed to form melanized appressoria (Table 1), which could have also been formed on other surfaces or substrates, according to XIAO et al. (1994).

The variable percentage of penetration and cell death indicates there were distinct interactions between the different pathogens and host plant species. Fungal penetration did not differ among the three host species following inoculation with the rice isolate; in 10 to $19 \%$ of the cases, it was observed that whenever there was appressorium formation, penetration also occurred (Table 3). In contrast, the fungal penetration percentage when inoculated with the wheat isolate was higher for wheat and $D$. sanguinalis than for $D$. insularis. Additionally, the penetration percentage of wheat plants by the wheat isolate was significantly higher than that of the rice isolate.

The germination and appressoria formation evaluated 48 hai revealed values above $70 \%$ (Table 2). M. oryzae spores

Table 1. Average percentage of Magnaporthe oryzae germinated spores and melanized appressoria 48 hours after inoculation in wheat and Digitaria plants, 2015 (Aquidauana, Mato Grosso do Sul, Brazil).

\begin{tabular}{lcc|} 
Species/cultivar & $\begin{array}{c}\text { Germinated } \\
\text { spores }\end{array}$ & $\begin{array}{c}\text { Melanized } \\
\text { appressoria }\end{array}$ \\
\hline Coodetec 150 & $95 \%$ A & $90 \%$ A \\
\hline Digitaria isularis & $19 \%$ B & $71 \%$ A \\
\hline Digitaria sanguinalis & $87 \%$ A & $97 \%$ A \\
\hline
\end{tabular}

Averages followed by the same letter in the column do not differ from each other by the Tukey test at $5 \%$ probability. 
germinate rapidly, even as quick as 2 hai (KOGA; NAKAYACHI, 2004; MARCHI et al., 2008; FAIVRE-RAMPANT et al., 2008). There are reports showing that environmental factors like temperature and leaf wetness significantly influence spore germination of Magnaporthe grisea. For instance, CARDOSO et al. (2008) observed that the severity of wheat blast disease was highest at temperatures between 25 and $30^{\circ} \mathrm{C}$ and with the presence of leaf wetness for longer than 24 hours.

The melanin in the appressoria of Magnaporthe species is crucial for successful infection, as this substance allows the turgor within the appressorium to increase, producing the mechanical force required for penetration (TALBOT, 2003). PTH11 gene has been reported to be responsible for melanin production; notably, its expression is induced by plant signals (RIOS-CARACUEL; TALBOT, 2007). MARCHI et al. (2008) evaluated M. grisea insertional mutants for this gene and observed deformed appressoria, altered pathogenicity in rice and, consequently, low incidence of the disease.

The melanization of appressoria is not affected by the species' resistance level, and it cannot be considered a resistance factor. Additionally, the formation of melanized appressoria has been observed in several substrates, independently of the presence of host tissue (XIAO et al., 1994).

Regarding cell death, no reaction was observed for the three host species inoculated with the wheat isolate, whereas they showed distinct behaviors when inoculated with the rice isolate. Interestingly, evidence of cell death was observed only

Table 2. Average percentages of germinated spores and melanized appressoria of Magnaporthe oryzae 48 hours after inoculation in wheat and Digitaria plants, 2015 (Aquidauana, Mato Grosso do Sul, Brazil).

\begin{tabular}{|lcc|} 
Isolate & $\begin{array}{c}\text { Germinated } \\
\text { spores }\end{array}$ & $\begin{array}{c}\text { Melanized } \\
\text { appressoria }\end{array}$ \\
\hline Rice & $70 \% \mathrm{~A}$ & $94 \% \mathrm{~A}$ \\
\hline Wheat & $72 \% \mathrm{~A}$ & $79 \% \mathrm{~A}$ \\
\hline
\end{tabular}

Averages followed by the same letter in the column do not differ from each other by the Tukey test at $5 \%$ probability.

Table 3. Average values of fungal penetration and cell death (with papilla signal) in wheat and Digitaria plants 48 hours after inoculation with Magnaporthe oryzae isolates, 2015 (Aquidauana, Mato Grosso do Sul).

\begin{tabular}{|c|c|c|c|c|}
\hline \multirow{3}{*}{ Specie/cultivar } & \multirow{2}{*}{\multicolumn{2}{|c|}{$\begin{array}{c}\text { Fungal } \\
\text { penetration } \\
\text { Isolate }\end{array}$}} & \multirow{2}{*}{\multicolumn{2}{|c|}{$\begin{array}{c}\text { Cell death } \\
\text { Isolate }\end{array}$}} \\
\hline & & & & \\
\hline & Rice & Wheat & Rice & Wheat \\
\hline Coodetec 150 & $19 \% \mathrm{Ab}$ & $78 \% \mathrm{Aa}$ & $36 \% \mathrm{Aa}$ & $0 \% A b$ \\
\hline Digitaria insularis & $15 \% \mathrm{Aa}$ & $\mathrm{O} \% \mathrm{Ba}$ & О\% Ba & $\mathrm{O} \% \mathrm{Aa}$ \\
\hline Digitaria sanguinalis & $10 \% \mathrm{Aa}$ & $43 \% \mathrm{Aa}$ & О\% Ba & O\% Aa \\
\hline
\end{tabular}

Averages followed by the same capital letter in the column or lowercase letter in the row do not differ among themselves by the Tukey test at $5 \%$ probability. in wheat and may have been caused by a defensive response involving specific recognition of the $M$. oryzae isolated from rice; this is supported by the fact that wheat plants inoculated with the wheat isolate had $78 \%$ fungal penetration, but lacked a cell death response (Table 3 ).

Fungal penetration into leaves occurs through rupture of the cuticle and epidermis caused by turgor pressure generated in the appressorium and formation of an infection hypha (FAIVRE-RAMPANT et al., 2008). According to GORIELY; TABOR (2006), the appressorial turgor pressure is $8 \mathrm{MPa}$. The average percentage of penetrating spores in the species analyzed was 19 and $78 \%$ for rice and wheat isolates, respectively (Table 3). Reduced values of penetration percentage could be considered as resistance characteristics. AHN et al. (2005) reported rice genotypes with low fungal penetration values, which may have been caused by the presence of chemical compounds or structures, or both, that promote the delay or prevention of pathogenic fungal penetration.

Plant responses involving cell death can be grouped into three types:

- cell death in response to the product of pathogen's avirulence genes, typically as a hypersensitive response during the initial stage of pathogen infection and colonization;

- cell death in response to pathogen toxins;

- cell death due to fatal damage during infection, mainly due to injuries, nutrient deficiency, or reduced function of cellular metabolism (YAO et al., 2002).

Cell death may indicate a resistance response to pathogens if accompanied by a reduction in infection. According to KOGA; NAKAYACHI (2004), rice plants resistant to $M$. oryzae showed a hypersensitive response in both intact and cut leaves. This process is not uniform and differs ultrastructurally (and probably biochemically) in each pathogen-host interaction (GRAICHEN et al., 2011).

The evaluated plant species exhibited interactions with pathogen isolates; this is probably due to strain-specific resistance found in these species. Previous reports on particular interactions between $M$. oryzae and wheat genotypes indicate that genes conferring resistance may be diverse and act specifically against particular pathogen races (URASHIMA et al., 2004). As observed by ARRUDA et al. (2005), resistance in some genotypes may be related to the developmental stage of the plant, since some showed resistance in the vegetative phase, but susceptibility in the reproductive phase.

\section{CONCLUSION}

The evaluated plant species showed different percentage of germinated spores, which may be attributable to structural characteristics (presence of trichomes, as well as preexistent 
defenses). Among the inoculants of $M$. oryzae, wheat plants isolates were the most aggressive as plants unable to recognize the pathogen, and, consequently, failed to activate defensive mechanisms such as cell death responses. In conclusion, the initial pathogenic inoculum in wheat crops could originate in other plant species, including some of the genus Digitaria.

\section{ACKNOWLEDGEMENTS}

The authors would like to thank Grande Dourados Federal University for the opportunity to improve and expand knowledge; Mato Grosso do Sul State University for space availability to carry out the experiment; and Coordination of Improvement of Higher Level Personnel (CAPES) for a research grant.

| | | | | | | | | | | | | | | | | | | | | | | | | | | | | | | | | | | | | | | | | | | | | | | | | | | | | | | | | | | | | | | | | | | | | | | | | | | | | | | | | | | | | | | | | | | | | | | | | | | | | | | | | | | | | | | | | | | | | | | | | | | | | | | | | | | | | | | | | | | | | | | | | | | | | | | | | | | | | | | | | | | | | | | | | | | | | | | | | | | | | | | | | | | | | | | | | | | | | | | | | | | | | || || REFERENCES

AHN, L.P.; KIM, S.; KANG, S.; SUH, S.C.; LEE, Y.H. Rice defense mechanisms against Cochliobolus miyabeanus and Magnaporthe grisea are distinct. Phytopathology, v.95, n. 11 , p.1248-1255, 2005. doi: 10.1094/PHYTO-95-1248

ARAÚJO, L.G.; PRABHU, A.S.; BARROS FREIRE, A. Development of blast-resistant somaclones of the upland rice cultivar Araguaia. Pesquisa Agropecuária Brasileira, v.35, n.2, p.357-367, 2000. http://dx.doi.org/10.1590/SO100-204X2000000200015

ARRUDA, M.A.; BUENO, C.R.N.C.; ZAMPROGNO, K.C.; LAVORENTI, N.A.; URASHIMA, A.S. Reação do trigo à Magnaporthe grisea nos diferentes estádios de desenvolvimento. Fitopatologia Brasileira, v.30, n.2, p.121-126, 2005. http://dx.doi.org/10.1590/ So $100-41582005000200003$

BEDENDO, I.P.; PRABHU, A.S. Doenças do arroz (Oryza sativa). In: KIMATI, H.; AMORIM, L.; REZENDE, J.A.M.; BERGAMIN FILHO, A.; CAMARGO, L.E.A. (Eds.) Manual de Fitopatologia Vol. 2: Doenças de Plantas Cultivadas. 4. ed. São Paulo: Agronômica Ceres, 2005. p.79-90.

BRAGAGNOLO, C.; SBRISSIA, G.F.; MAFIOLETTI, R.L. Triticultura brasileira: desafios e perspectivas. Anuário da Agricultura Brasileira. São Paulo: Agra FNP - Instituto FNP, 2007. p. 497-498.

CARDOSO, C.A.A.; REIS, E.M.; MOREIRA, E.N. Development of a warning system for wheat blast caused by Pyricularia grisea. Summa Phytopathologica, v.34, n.3, p.216-221, 2008. http:// dx.doi.org/10.1590/SO100-54052008000300002

COMPANHIA NACIONAL DE ABASTECIMENTO (CONAB). $11^{\circ}$ Levantamento Grãos Safra 2016-2017. Available from: <https://www.conab.gov.br/info-agro/safras/grãos/boletim-dasafra-de-graos?start=10>. Access on: 15 Aug. 2017.

CRUZ, M.F.A.; PRESTES, A.M.; MACIEL, J.L.N.; SCHEEREN, P.L. Resistência parcial à brusone de genótipos de trigo comum e sintético nos estádios de planta jovem e de planta adulta. Tropical Plant Pathology, v.35, n. 1, p.24-31, 2010. http://dx.doi. org/10.1590/S1982-56762010000100004

GALBIERI, R.; URASHIMA, A.S. Caracterização, compatibilidade e ocorrência de reprodução sexual entre isolados de Pyricularia grisea de diferentes hospedeiros. Summa Phytopathologica, v.34, n.1, p.22-28, 2008. http://dx.doi.org/10.1590/ So $100-54052008000100005$
GORIELY, A.; TABOR, M. Estimates of biomechanical forces in Magnaporthe grisea. Mycological Research, v. 110 (Pt 7), p.755759, 2006. DOI: 10.1016/j.mycres.2006.03.014

GOULART, A.C.P.; PAIVA, F.A.; ANDRADE, P.J.M. Relação entre a incidência da brusone em espigas de trigo e a presença de Pyricularia grisea nas sementes colhidas. Fitopatologia Brasileira, v.20, n.2, p.184-189, 1995.

.; SOUSA, P.G.; URASHIMA, A.S. Danos em trigo causados pela infecção de Pyricularia grisea. Summa Phytopathologica, v.33, n.4, p.358-363, 2007. http://dx.doi.org/10.1590/ S0 $100-54052007000400007$

GRAICHEN, F.A.S.; MARTINELLI, J.A.; GUTERRES, C.W.; CHAVES, M.S.; FEDERIZZI, L.C. Epidemiological and histological components of oat crown rust resistance in oat genotypes. European Journal of Plant Pathology, v.131, n.3, p.497-510, 201 1. DOI: 10.1007/ s10658-011-9825-z

IGARASHI, S.; UTIAMADA, C.M.; IGARASHI, L.C.; KAZUMA, A.H.; LOPES, R.S. Pyricularia em trigo 1. Ocorrência de Pyricularia sp. no estado do Paraná. Fitopatologia Brasileira, v.1 1, p.351-352, 1986.

KOGA, H.; NAKAYACHI, O. Morphological studies on attachment of spores of Magnaporthe grisea to the leaf surface of rice. Journal of General Plant Pathology, v.70, n. 1, p.11-15, 2004.

LIMA, M.I.P.M. Giberela ou Brusone: orientações para a identificação correta dessas enfermidades em trigo e em cevada. Embrapa Trigo Documento Online 40, 2004.

MARCHI, C.E.; BROMMONSCHENKEL, S.H.; QUEIROZ, M.V.; BORGES, M.F.; MIZUBUTI, E.S.G. Mutantes insercionais de Magnaporthe grisea com patogenicidade alterada em arroz. Tropical Plant Pathology, v.33, n.1, p.55-62, 2008. http://dx.doi.org/10.1590/ S1982-56762008000100009

MOREIRA, S.I.; CERESINI, P.C.; ALVES, E. Reprodução sexuada em Pyricularia oryzae. Summa Phytopathologica, v.41,n.3, p.175182, 2015. http://dx.doi.org/10.1590/0100-5405/2067

FAIVRE-RAMPANT, O.; THOMAS, J.; ALLĖGRE, M.; MOREL, J.B.; THARREAU, D.; NOTTÉGHEM, J.L.; LEBRUN, M.H.; SCHAFFRATH, U.; PIFFANELLI, P. Characterization of the model system Rice Magnaporthe for the study of nonhost resistance in cereals. New Phytologist, v. 180 , n.4, p.899-910, 2008. doi: 10.1111/j.1469-8137.2008.02621.x 
RIOS-CARACUEL, Z.; TALBOT, N.J. Cellular differentiation and host invasion by the rice blast fungus Magnaporthe grisea. Current Opinion in Microbiology, v.10, n.4, p.339-345, 2007. DOI: 10.1016/j.mib.2007.05.019

ROCHA, J.R.A.S.C.; PIMENTEL, A.J.B.; BIBEIRO, G.; SOUZA, M.A. Eficiência de fungicidas no controle da brusone em trigo. Summa Phytopathologica, Campinas, v.40, n.4, p.347-352, 2014. http:// dx.doi.org/10.1590/0100-5405/1937

TALBOT, N.J. On the trail of a cereal killer: exploring the biology of Magnaporthe grisea. Annual Review of Microbiology, v.57, p.177202, 2003. DOI: 10.1146/annurev.micro.57.030502.090957

URASHIMA, A.S.; LAVORENTI, N.A.; GOULART, A.C.P.; MEHTA, Y.R. Resistance spectra of wheat cultivars and virulence diversity of Magnaporthe grisea isolates in Brazil. Fitopatologia Brasileira, v.29, n.5, p.511-518, 2004. http://dx.doi.org/10.1590/ S0100-41582004000500007

.; LEITE, S.F.; GALBIERI, R. Eficiência da disseminação aérea em Pyricularia grisea. Summa Phytopathologica, v.33, n.3, p.275-279, 2007. http://dx.doi.org/10.1590/ So $100-54052007000300011$ van WEES. Phenotypic Analysis of Arabidopsis Mutants: Trypan Blue Stain for fungi, Oomycetes, and dead plant cells. Cold Spring Harbor Protocols, 2008. Available from: <http://cshprotocols.cshlp.org/cgi/content/abstract/2008/9/ pdb.prot4982>. Access on: 24 Jul. 2013.

WYSS, G.S.; MÜLLER-SCHÄRER, H. Infection process and resistance in the weed pathosystem Senecio vulgaris - Puccinia lagenophorae and implications for biological control. Canadian Journal of Botany, v.77, n.3, p.361-369, 1999. https://doi. org/10.1139/b99-006

XIAO, J.-Z.; WATANABE, T.; KAMAKURA, T.; OHSHIMA, A.; YAMAGUCHI, I. Studies on cellular differentiation of Magnaporthe grisea. Physicochemical aspects of substratum surfaces in relation to appressorium formation. Physiological and Molecular Plant Pathology, v.44, n.3, p.227-236, 1994. https://doi.org/10.1016/ S0885-5765(05)80007-4

YAO, N.; IMAI, S.; TADA, Y.; NAKAUASHIKI, H.; ROSSA, Y.; PARK, P.; MAYAMA, S. Apoptotic cell death is a common response to pathogen attack in oats. Molecular Plant-Microbe Interaction, v.15, n.10, p.1000-1007, 2002. DOI: 10.1094/ MPMI.2002.15.10.1000 